\title{
Characterization of Indian Isolates of Fusarium oxysporum f. sp. ciceri Causing Chickpea Wilt
}

\author{
B.B. Golakiya*, M.D. Bhimani and L.F. Akbari \\ Department of Plant Pathology, College of Agriculture, JAU, Junagadh-362001, India \\ *Corresponding author
}

\begin{tabular}{|l|}
\hline Ke y w o r d s \\
$\begin{array}{l}\text { Fusarium oxysporum f. } \\
\text { sp. ciceri, Chickpea, PDI, } \\
\text { Chlamydospores }\end{array}$ \\
\hline Article Info \\
\hline $\begin{array}{l}\text { Accepted: } \\
\text { 10 February } 2018 \\
\text { Available Online: } \\
10 \text { March } 2018\end{array}$ \\
\hline
\end{tabular}

\section{Introduction}

Chickpea (Cicer arietinum L.) is the world's fourth most important legume crop after soybean, common bean, and peas.

In developing countries, chickpea is a rich complement to the cereal diet since it has a high nutritive value. Mainly grown for its highly proteinated edible seeds, this crop can be used for both seed and forage production (Yadav et al., 2011).
Fusarium oxysporum (Schletend: Fr) f. sp. ciceri (Padwick) (FOC) is a soil borne fungus that is a permanent threat to the chickpea (Cicer arietinum L.) causing wilt disease. Chickpea plant showing typical wilt symptoms were collected from fifteen different locations of Saurashtra including Ghed regions of Gujarat. Isolation from diseased roots portion of wilted plant were carried out which yielded species of Fusarium with different cultural and morphological characters on potato dextrose agar media. Koch's postulates were performed by standard method for all fifteen isolates and they gave different response in form of varied disease incidence. On the basis of cultural, morphological, molecular characteristics and pathogenicity test, the fungus was confirmed as $F$. oxysporum Schlechtend. Fr. f. sp. ciceri (Padwick) Matuo and K. Sato. The pathogenic nature of fifteen isolates tested on chickpea wilt susceptible cultivar JG-62, two isolate (Char, Choki) were found non-pathogenic gave zero per cent disease incidence (PDI), while one isolate (Chittal) found highly pathogenic with 100 per cent PDI which was further used for molecular identification and screening of agro-chemicals. Study of cultural characters and conidial morphology of different isolates were carried out which showed variation in growth habit, pigmentation, sporulation, shape and size of macro and micro conidia, structure and size of chlamydospores, etc. 
estimates indicated that losses around 10-15 per cent each year as regular feature. In the years of severe epidemics, crop losses will go as high as 60-70 per cent (Jalali and Chand, 1992).

$F$. oxysporum f. sp. ciceri is a highly variable pathogen. Eight races of this pathogen have been reported, of which six (1A, 2, 3, 4, 5 and 6) cause wilting symptoms (Gowda et al., 2009). Four FOC races (1A, 2, 3 and 4) are prevalent in India, of these the race 1A is most virulent.

Management of the disease is difficult either through crop rotation or application of fungicides because of its soil borne nature. Instead, the use of wilt resistant chickpea cultivars is potentially the most effective and eco-friendly method of managing the disease (Jalali and Chand, 1992). However, the high pathogenic variability in the FOC may limit the effectiveness of resistance (Haware and Nene 1982). The pathogen can survive in soil for up to six years even in the absence of the host (Haware et al., 1996).

Presently the information in order to strengthen the breeding efforts that aims at boosting chickpea productivity and production through the development of wilt resistant chickpea varieties, this study was undertaken with the aims of assessing the pathogenic, cultural, morphological and molecular variability in isolates of $F$. oxysporum $\mathrm{f}$. sp. ciceri, causing chickpea wilt.

\section{Materials and Methods}

\section{Sample collection, isolation and purification}

Chickpea plants, naturally infected and showing typical wilt were collected from fifteen different locations of Saurashtra and Ghed regions which includs Gir Somnath, Jamnagar, Porbandar, Amreli and Junagadh districts of Gujarat. Isolation of the fungus was made by tissue isolation technique. The resulting fungal cultures were purified by hyphal tip method. Purified cultures were maintained on PDA slants by storing it under refrigeration at $4{ }^{\circ} \mathrm{C}$. To maintain the culture for further studies, periodical transfers were made once in a month. The fungus was isolated, purified and sub cultured in aseptic condition under a laminar flow.

The isolates of the pathogen were primarily identified based on colony characters and spores morphology (Booth, 1971). Photomicrographs of the $F$. oxysporum $\mathrm{f}$. sp. ciceri isolates were taken by using imaging microscope to describe spore morphology.

\section{Pathogenicity of isolates}

The fifteen isolates were screened for their pathogenicity on chickpea wilt susceptible cultivar JG-62 during rabi season 2016-17 under net-house.

The inoculum of each isolates of Fusarium oxysporum f. sp. ciceri was prepared on half boiled sorghum media and incubated at $28^{0} \mathrm{C}$ for 10 days. These inoculums were used for soil inoculation at $40 \mathrm{~g} \mathrm{~kg}^{-1}$ soil in all the pots (Kala et al., 2016).

For each isolate, set of three pots $(15 \mathrm{~cm}$ width x $15 \mathrm{~cm}$ depth) were prepared. One set of pot constituting three pots to be filled with sterilized soil only. These pots were considered as uninoculated control. Three test tubes were inserted at equidistance and about $6 \mathrm{~cm}$ deep in each pot for supplementary inoculation.

Eight chickpea seeds of wilt susceptible cultivar JG-62 were sown in each pot. Germination was counted eight DAS. Watering was done as and when required. The plants were observed regularly for the 
appearance and development of disease symptoms. Secondary inoculation done by adding inoculum prepared on potato dextrose broth. Liquid culture $(30 \mathrm{ml} / \mathrm{pot})$ along with piece of mycelial met $\left(2 \times 10^{7} \mathrm{cfu} / \mathrm{ml}\right)$ inoculated in hole made by removal of test tubes so that inoculum was directly leached to the root zone.

Inoculation was done in all pots, except control. As the symptoms of disease appeared, the fungus was re-isolated from the roots of diseased plant and the re-isolated fungus was brought to pure culture, which was later compared with the original one.

The per cent wilt incidence was calculated by following formula.

Total number of wilted plants per pot Per cent Disease Incidence = ------------- x 100 Total number of plants per pot

Cultural, morphological and molecular characters of different isolates of Fusarium oxysporum f. sp. ciceri

\section{Cultural and morphological studies}

All fifteen isolates of $F$. oxysporum f. sp. ciceri were separately grown on PDA in Petriplates and incubated at $28 \pm 2^{\circ} \mathrm{C}$ for seven days.

Observations on cultural characters viz., colony colour and type, growth and pigmentation were recorded a week after inoculation.

Morphological characters of spores of different isolates were studied by observing in cotton blue stained slides under imaging microscope. Measurements of macro-micro conidia and chlamydospores were made with the help of imaging microscope which shows size of conidia and diameter of chlamydospores. Sporulation was recorded by microscopic examinations using following scale given by Tuite (1969).

\section{Molecular characterization}

Two isolates which was found highly virulent during pathogenicity test were identified using molecular tools by following procedure:

\section{Fungal DNA isolation and sequencing}

The fungal genomic DNA was extracted from mycelia grown in $250 \mathrm{ml}$ of PDB at $28{ }^{\circ} \mathrm{C}$ for 5 days. The mycelia were harvested from broth and lyophilised and stored at $-20{ }^{\circ} \mathrm{C}$ for further process. The genomic DNA for PCR was extracted by using HiMedia fungi DNA isolation kit. The ITS region of fungi, including ITS2 (5'-GCTGCGTTCTT CATCGATGC-3'), ITS1 (5'-TCCGTAGGT GAACCTGCGG-3') and ITS4 (5'TCCTCCGCTTATTGATATGC-3') were amplified. The amplification was performed in $30 \mu \mathrm{l}$ reaction volume with $0.1 \mathrm{mM}$ of each dNTP and 100pmol of both forward and reverse primer. Veriti PCR (Thermo fisher) was programmed for initial denaturation at 94 ${ }^{\circ} \mathrm{C}$ for $4 \mathrm{~min}$, and 35 cycles at $94{ }^{\circ} \mathrm{C}$ for $1 \mathrm{~min}$, $55{ }^{\circ} \mathrm{C}$ for $1 \mathrm{~min}$, and $72{ }^{\circ} \mathrm{C}$ for $1 \mathrm{~min}$. The amplification was completed with a final extension at $72^{\circ} \mathrm{C}$ for $5 \mathrm{~min}$. Further it was sequenced by ABI 3130 capillary sequencing. After sequencing, identification of fungal sequences were analysed using BLAST (https://blast.ncbi.nlm.nih.gov/Blast.cgi).

\section{Results and Discussion}

The pathogen

\section{Isolation and purification of pathogen}

The wilt affected chickpea plants were identified in the field based on key symptoms like withering, yellowing of leaves and drying 
of plants. Roots of wilt infected plants when split open vertically showed brown discoloration of the xylem vessels. The pathogen was isolated from wilt affected plants using tissue segment method on PDA. The fungus was further purified by single hyphal tip method on PDA. Pure culture was depicted in figure 1 .

Similar methodology was followed by Rangaswami and Mahadevan (1999) for isolation of the pathogen from wilt infected chickpea plants.

\section{Pathogenicity of isolates}

Pathogenicity of fifteen isolates of Fusarium oxysporum f. sp. ciceri were tested on chickpea wilt susceptible cultivar JG-62 by "Soil inoculation method" as described under "Materials and Methods". Pathogenicity test indicated that these isolates varied in the percentage of infection.

Among the all isolates, highest disease incidence was recorded in Chittal isolate with 100 per cent disease incidence, in Ghusiya and Madhavpur isolates PDI were 87.5 per cent. M. F. (Model farm J.A.U.), Balagam and Khadpipali isolates showed 75 per cent PDI followed by Vagudal and S. F isolate $(62.5 \%$ PDI). Bhatiya isolate found least pathogenic showed only 25 per cent disease incidence while, Char and Choki isolates were found non-pathogenic (Table 1).

This result indicates that the different isolates of fungi, isolated from the infected roots may or may not be pathogenic. Hence, once the isolate/s received in pure culture requires to be tested further for their pathogenicity so the pathogenic culture to be used for remaining laboratory and field trials.

Our results were in agreement with that of Nikam et al., (2011) who confirmed pathogenicity of the Fusarium oxysporum f. sp. ciceri by sick soil inoculation technique in earthen pots under green-house conditions using susceptible cultivar JG-62.

\section{Identification of the pathogen}

\section{Cultural identification}

Observations on cultural characters of Fusarium oxysporum f. sp. ciceri viz., colony color, growth, pigmentation and sporulation were recorded a week after inoculation and presented in Table 2.

The cultural characteristics of 15 isolates of Fusarium oxysporum f. sp. ciceri revealed that isolates differed in colony type and growth habit, pigmentation and sporulation. Majority of the isolates showed pale white to typical cottony white colony colour. The isolates also differed in their mycelial arrangement and growth habit (Fig. 2). On the basis of the mycelial growth pattern, the isolates were categorized into two groups' i.e. sparse growth and dense growth. Most of the isolates had dense or sparse growth with smooth margin, while dense growth with irregular margin was present in Madhavpur, Chittal and P.R.F. (Pulse Research Farm, Junagadh) isolates. Sparse growth with irregular margin was observed in Vagudal, Thari, and Bhatiya isolates.

Typical pale yellow pigmentation was observed in most of the isolates even after one month of incubation, whereas two isolates viz., Chittal and Toraniya isolates had brown pigmentation. Nandarkhi isolate showed light brown pigmentation.

Ghusiya, Madhavpur, Chittal, P.R.F., M.F., S.F. and Balagam isolates showed good sporulation. Six isolates with moderate sporulation were Vagudal, Nandarkhi, Thari, Toraniya, Khadpipali and Choki isolates. Poor sporulation was observed in Char and Bhatiya isolates. 
Table.1 Variation in wilt incidence among different isolates of Fusarium oxypsorum f. sp. cicero

\begin{tabular}{|c|c|c|c|c|}
\hline Sr. No & $\begin{array}{c}\text { Isolates/ } \\
\text { Designation }\end{array}$ & Total plants/pot & $\begin{array}{l}\text { Total Wilted } \\
\text { plant(s)* }\end{array}$ & $\begin{array}{c}\text { Per cent } \\
\text { Disease Incidence* }\end{array}$ \\
\hline 1. & Ghusiya & 8 & 7 & 87.50 \\
\hline 2. & Vagudal & 8 & 5 & 62.50 \\
\hline 3. & Madhavpur & 8 & 7 & 87.50 \\
\hline 4. & Chittal & 8 & 8 & 100.0 \\
\hline 5. & Nandarkhi & 8 & 4 & 50.00 \\
\hline 6. & Thari & 8 & 3 & 37.50 \\
\hline 7. & Char & 8 & 0 & 0.00 \\
\hline 8. & Toraniya & 8 & 3 & 37.50 \\
\hline 9. & P.R.F.* & 8 & 4 & 50.00 \\
\hline 10. & M.F.* & 8 & 6 & 75.00 \\
\hline 11. & S.F.* & 8 & 5 & 62.50 \\
\hline 12. & Bhatiya & 8 & 2 & 25.00 \\
\hline 13. & Balagam & 8 & 6 & 75.00 \\
\hline 14. & Khadpipali & 8 & 6 & 75.00 \\
\hline 15. & Choki & 8 & 0 & 0.00 \\
\hline
\end{tabular}

* - P.R.F.- Pulse Research Farm, Junagadh, M.F. - Model farm J.A.U., S.F.- Sagdividi farm J.A.U.

Table.2 Colony characters of different isolates of Fusarium oxypsorum f. sp. ciceri

\begin{tabular}{|c|c|c|c|c|c|}
\hline $\begin{array}{l}\text { Sr. } \\
\text { No. }\end{array}$ & Isolates & $\begin{array}{c}\text { Mycelial arrangement } \\
\text { and colour }\end{array}$ & Pigmentation & $\begin{array}{l}\text { Growth } \\
\text { habit }\end{array}$ & Sporulation* \\
\hline 1 & Ghusiya & Dense Cottony white & Pale yellow & Moderate & +++ \\
\hline 2 & Vagudal & Sparse Cottony white & Pale yellow & Slow & ++ \\
\hline 3 & Madhavpur & Dense Dirty white & Pale yellow & Moderate & ++++ \\
\hline 4 & Chittal & Dense Cottony white & Brown & Fast & ++++ \\
\hline 5 & Nandarkhi & Sparse Dirty white & Light Brown & Moderate & ++ \\
\hline 6 & Thari & Sparse Cottony white & Pale yellow & Slow & ++ \\
\hline 7 & Char & Sparse Cottony white & Pale yellow & Moderate & + \\
\hline 8 & Toraniya & Dense Dirty white & Brown & Moderate & ++ \\
\hline 9 & P.R.F. & Dense Cottony white & Pale yellow & Fast & +++ \\
\hline 10 & M.F. & Dense Cottony white & Pale yellow & Fast & +++ \\
\hline 11 & S.F. & Dense Cottony white & Pale yellow & Fast & +++ \\
\hline 12 & Bhatiya & Sparse Cottony white & Pale yellow & Slow & + \\
\hline 13 & Balagam & Sparse Cottony white & Pale yellow & Slow & +++ \\
\hline 14 & Khadpipali & Dense Dirty white & Pale yellow & Moderate & ++ \\
\hline 15 & Choki & Dense Dirty white & Pale yellow & Fast & ++ \\
\hline
\end{tabular}

* + Poor, ++ Moderate, +++ Profuse, ++++ Abundant 
Table.3 Measurement of macro, microconidia and chlamydospore of different isolates

\begin{tabular}{|l|l|c|c|c|c|c|}
\hline \multirow{2}{*}{ Sr.no } & \multicolumn{1}{|c|}{ Isolates } & \multicolumn{2}{|c|}{ Microconidia* } & \multicolumn{2}{c|}{ Macroconidia* } & Chlamydospores \\
\cline { 3 - 6 } & $\begin{array}{c}\text { Length } \\
(\boldsymbol{\mu m})\end{array}$ & $\begin{array}{c}\text { Width } \\
(\boldsymbol{\mu m})\end{array}$ & $\begin{array}{c}\text { Length } \\
(\boldsymbol{\mu m})\end{array}$ & $\begin{array}{c}\text { Width } \\
(\boldsymbol{\mu m})\end{array}$ & $\begin{array}{c}\text { Diameter } \\
(\boldsymbol{\mu m})\end{array}$ \\
\hline $\mathbf{1}$ & Ghusiya & 10.09 & 4.56 & 22.46 & 5.68 & 09.01 \\
\hline $\mathbf{2}$ & Vagudal & 9.89 & 2.59 & 16.05 & 4.40 & 07.06 \\
\hline $\mathbf{3}$ & Madhavpur & 9.99 & 3.41 & 18.19 & 5.12 & 10.79 \\
\hline $\mathbf{4}$ & Chittal & 11.66 & 3.86 & 22.89 & 5.99 & 06.53 \\
\hline $\mathbf{5}$ & Nandarkhi & 9.45 & 3.64 & 16.16 & 3.99 & 07.64 \\
\hline $\mathbf{6}$ & Thari & 10.21 & 4.50 & 17.15 & 4.91 & 14.99 \\
\hline $\mathbf{7}$ & Char & 09.68 & 4.44 & 24.09 & 5.15 & 10.16 \\
\hline $\mathbf{8}$ & Toraniya & 15.98 & 4.49 & 20.78 & 5.03 & 07.29 \\
\hline $\mathbf{9}$ & P.R.F. & 10.85 & 3.14 & 17.45 & 4.07 & 09.59 \\
\hline $\mathbf{1 0}$ & M.F. & 10.05 & 3.48 & 23.32 & 5.84 & 12.55 \\
\hline $\mathbf{1 1}$ & S.F. & 15.52 & 4.34 & 21.62 & 4.86 & 07.46 \\
\hline $\mathbf{1 2}$ & Bhatiya & 16.10 & 4.82 & 21.23 & 5.22 & 10.04 \\
\hline $\mathbf{1 3}$ & Balagam & 14.18 & 4.24 & 20.48 & 4.94 & 11.26 \\
\hline $\mathbf{1 4}$ & Khadpipali & 09.85 & 3.91 & 17.64 & 4.78 & 09.38 \\
\hline $\mathbf{1 5}$ & Choki & 12.76 & 3.68 & 16.24 & 3.85 & 08.61 \\
\hline
\end{tabular}

*mean of 10 spores from two microscopic fields

Table.4 Sequence data of two isolates

\begin{tabular}{|c|c|c|}
\hline Isolates & Sequence & Identical (\%) \\
\hline Ghusiya & $\begin{array}{l}\text { AAATGTTTGATGACAGTCGAGAGGGACATTACCGAGTTATACAACTCATCAACC } \\
\text { CTGTGAACATACCTATAACGTTGCCTCGGCGGGAACAGACGGCCCCGTAACACG } \\
\text { GGCCGCCCCGCCAGAGGACCCCCAACTCTGTTCTATAATGTTTCTCTGAGT } \\
\text { AAACAAGCAAATAAATTAAAACTTTCAACAACGGATCTCTTGGCTCTGGCATCG } \\
\text { ATGAAGAACGCAGCGAAATGCGATAAGTAATGTGAATTGCAAAATTCAGTGAAT } \\
\text { CATCGAATCTTTGAACGCACATTGCGCCCGCCAGATTCTGGCGGGCATGCCTGT } \\
\text { TCGAGCGTCATTACAACCCTCAGGCCCCCGGCCTGGCGTTGGGGATCGGCGGA } \\
\text { GGCCCCCTGCGGGCACAACGCCCCCCACCCAAATACGGGGGGCCCGCCCGGCC } \\
\text { GTAATCTTCGTTTGAAAAGTAAATCCCCCCTCAGAAGGGGGGAGGGGCCCGGGC } \\
\text { CGTTAAAAAACCCACACTTCCTCTTGGGGTTTGCCAACTCAGGATCAGAATAGC } \\
\text { CAACTTGAATTTGTGTCTTTTATCAAATAGGCGGAAGGCAAAAAAAAACAAAAG } \\
\text { GGGAATGGGTCTCTTGTTATCTATTGTAGCTGTGAGAAGTGCCACAAGACTAAA } \\
\text { AATTTTTTGAAATACACGAGATTCTTCTGGGGCGCGCAGACTTTGTGAAGATTT } \\
\text { GGTAGAAGAGATAGCTTTTTTTGGGTGGACGGTGTTGCTTTTCTCCGAGCGTTA } \\
\text { CGCCTGGAGCGATTGTGTGAGAGCGTACTAGTTATCAACGAGGTGGATTGAGA } \\
\text { CTCGCCACCGATTGCTTGTGTAATCGGTGCACGACCTCAGAATGTACTTCTTCTT } \\
\text { GTCTCAGACATGTCGTTTCCTCTTATACGAAACCGAAGATGCGAACGTTTGTTTA } \\
\text { TCCGTGACCATATGTTCTAGTCACTCTTTTATCCC } \\
\text { ATCTATCTTATCGCGTTG (KP992931.1) }\end{array}$ & $\begin{array}{l}\text { Fusarium } \\
\text { oxysporum } \\
\text { Strain } \\
\text { (94\% identity) }\end{array}$ \\
\hline Chittal & $\begin{array}{l}\text { GCCTTCTTGGTGACAGTCGGAGGGATCATTACCGAGTTATACAACTCATCAACCC } \\
\text { TGTGAACATACCTATAACGTTGCCTCGGCGGGAACAGACGGCCCCGTAACACGG } \\
\text { GCCGCCCCGCCAGAGGACCCCTAACTCTGTTCTATAATGTTCTTCTGAGTA } \\
\text { AACAAGCAAATAAATTAAAACTTTCAACAACGGATCTCTTGGCTCTGGCATCGA } \\
\text { TGAAGAACGCAGCGAAATGCGATAAGTAATGTGAATTGCAGAATTCAGTGAATC } \\
\text { ATCGAATCTTTGAACGCACATTGCGCCCGCCAGTATTCTGGCGGGCATGCCTGTT } \\
\text { CAAGCGTCATTGCAACCCTCAGGCCCCGGATCTGGCGTTGGATCGGACCATAC } \\
\text { CTCTACTCGACCGACGCCTCCCCCAAATACCGTGGCGTCCCCGCCGAATTTTCC } \\
\text { CATTGGCTAAAACTTACCCCCCTCGAAACTTGGGGGGGGGGGCGGGGGCCCCCC } \\
\text { CCGAAAAACCCCCCCACTTTCCGAATGGTTTAACCTCCGAAATCCAGGGTAGTA } \\
\text { ATTCCCCTCCTTAAACTTTAACCTTATCCCCCCCCCGAAAGAAAAAGAAAAGCC } \\
\text { TATTTTGGTCATTGGTCCCAAATTAAAGGGGGGGGGGGGCAACCGTATAACATT } \\
\text { TTTTAAAATTTTTAAAATTTTTGG (KU671029.1) }\end{array}$ & $\begin{array}{l}\text { Fusarium } \\
\text { oxysporum } \\
\text { Strain } \\
\text { (97\% } \\
\text { Identity) }\end{array}$ \\
\hline
\end{tabular}




\section{Cultural and Morphological studies}

\begin{tabular}{c|l|l|}
- & $=$ & Absent \\
+ & $=$ & Scanty $(1-10$ spore/MF $)$ \\
\hline++ & $=$ & Poor $(11-20$ spores $/ M F)$ \\
\hline+++ & $=$ & Good $(21-30$ spores/MF $)$ \\
\hline++++ & $=$ & Abundant $(>30$ spores $/ M F)$
\end{tabular}

Where, MF denotes Microscopic field.

Fig.1 Pure culture of Fusarium oxysporum f. sp. ciceri

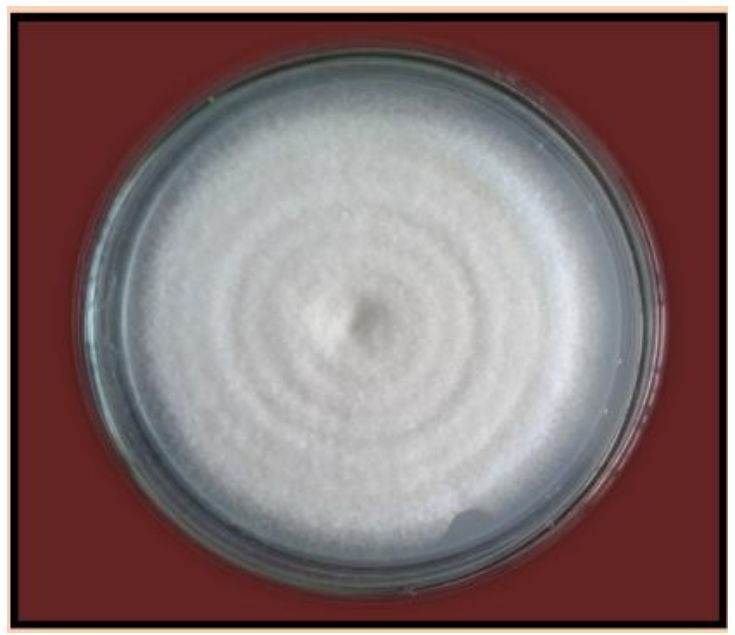

Fig.2 Cultural characters of different isolates of Fusarium oxysporum f. sp. cicero

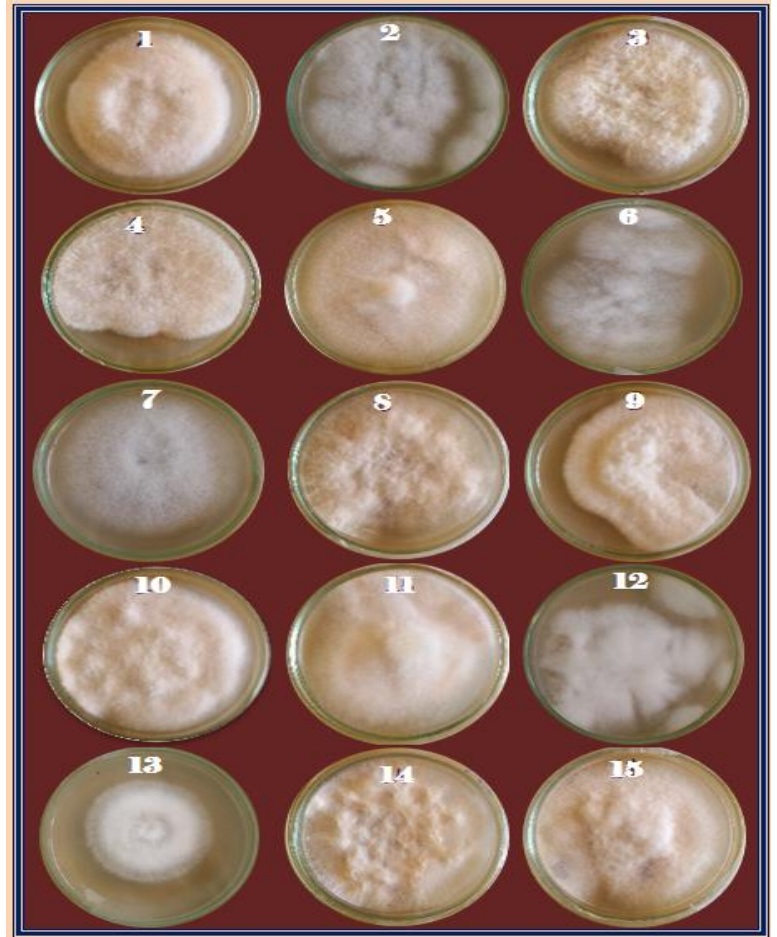


Fig.3 a) Microconidia, b) Macroconodia

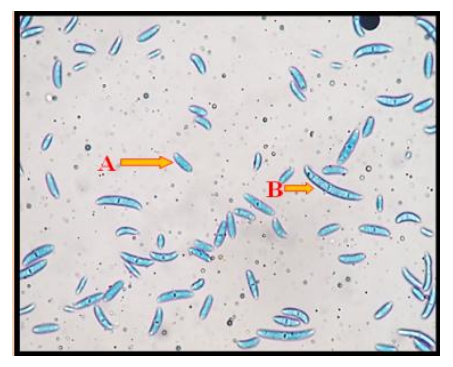

Fig.4 a) Chlamydospore, b) Mycelium

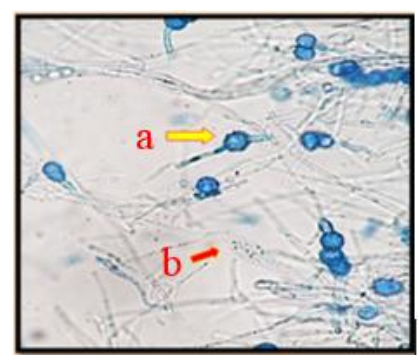

It is revealed from these observations that sporulation has relevance with virulence of the isolates. The isolates produced abundant sporulation were highly virulent, while poor to moderately sporulated isolates produce very low per cent pathogenicity or were nonpathogenic.

Based on the growth habit, the isolates were categorized into three groups viz., fast growing, moderate growing and slow growing. Five isolates: Chittal, P.R.F., M.F., S.F. and Choki isolates showed fast growth habit, while four isolates: Vagudal, Thari, Bhatiya and Balagam isolates showed slow growth habit and the remaining six isolates have moderate in growth habit. In the present investigation common characters for the highly virulent isolates were sparse to dense mycelial growth, pale yellow pigmentation, moderate to fast growth habit and abundant sporulation.

Working with wilt of chickpea, Prasad and Padwick (1939); Chauhan (1962); Grewal et al., (1974); Gupta et al., (1986); Barhate et al., (2006); Pande et al., (2007); Sharma et al., (2009); Gurjar et al., (2012) was also reported the pathogenic variability within the isolates of $F$. oxysporum f. sp. ciceri. Paulkar and Raut (2004) also reported such variations in mycelial growth pattern. Variation in pigmentation viz., brownish, light yellow and violet within the isolates have been reported by several workers (Gupta et al., 1986; Agarwal and Gupta, 2006; Groenewald et al., 2006 and Patel and Anahosur, 2001).

Honnareddy and Dubey (2007) found differences in respect of their colony colour, pigmentation of substrate, growth rate, presence of macro conidia and virulence on susceptible variety L 550. According to Dubey et al., (2010); Mandhare et al., (2011) and Rosa et al., (2011), Fusarium wilt isolates were highly variable in their colony growth pattern, size of colony and pigmentation, which are in conformity with present investigation. Singh et al., (2010) also observed dull white to pinkish white, thin and flat hairy to fluffy growth with irregular margins. 


\section{Morphological identification}

The fungus Fusarium oxysporum f. sp. ciceri produce two types of conidia viz., microconidia (small in size) and macroconidia (bigger in size). The conidial width and length of 15 isolates were measured and presented in Table 3 and depicted in Figure 3a.

Microscopic observation revealed that the microconidia (Fig. 3a) in all isolates were small, one to two celled, hyaline with oval to reniform and oval to oblong with slightly curved shape. Its length ranged from 9.45 to $16.10 \mu \mathrm{m}$, while width ranged from 2.59 to $4.82 \mu \mathrm{m}$. The measurement of microconidia varied considerably.

Macroconidia (Fig. 3b) in all these isolates were long, variable in size and shape, somewhat of uniform width except at the end, curved toward the end where they were narrow, blunt and smoothly rounded or pointed at the tip, mostly 2-3 septate and hyaline in colour. Its length ranged from 16.05 to $24.09 \mu \mathrm{m}$, while the width ranged from 3.85 to $5.99 \mu \mathrm{m}$.

In old culture, chlamydospores were formed, which were rough or smooth walled, intercalary or terminal and may be formed singly, in chains or pairs (Fig. 4a). Variation among diameter of chlamydospore is presented in table 3. Chlamydospore of Thari isolate was found large in size measuring $14.99 \mu \mathrm{m}$ diameter while Chittal isolate having comparatively small $(06.53 \mu \mathrm{m})$ chlamydospore.

The comparison between size and septation in macro, micro conidia and chlamydospore of pathogenic and non-pathogenic did not gave clear picture; hence it is clearly observed in the present study that conidial measurement has no relevance with its virulence. This has been supported by Patil et al., (2005) who revealed that the isolates of $F$. oxysporum $\mathrm{f}$. sp. ciceri had variation in number and size of macro and microconidia, cultural characters, growth pattern, pigmentation and sporulation.

Dubey et al., (2010) reported that size of microconidia varied from 5.1-12.8 x 2.5-5.0 $\mu \mathrm{m}$ whereas macroconidia ranged from 16.5 37.9 x $4.0-5.9 \mu \mathrm{m}$ with $1-5$ septations. Gupta et al., (1986) noticed that size of microconidia varied from 3.88-9.99 x 1.66-4.99 $\mu \mathrm{m}$ whereas macroconidia ranged from 16.65$66.60 \times 3.33-6.66 \mu \mathrm{m}$. In the present study also such dimensions of micro and macro conidia in different isolates of $F$ oxysporum $\mathrm{f}$. sp. ciceri have been observed.

\section{Molecular Identification}

Among fifteen isolates, Ghusiya and Chittal isolates were selected (Table 4) for molecular identification based on their virulence proved during pathogenicity test.

Sequencing was done by following procedure as described in section 3.4.2. At the end of the procedure, sequence was found for both of the isolates which was BLAST online in NCBI data base and concluded that the pathogen associated with wilt of chickpea was Fusarium oxysporum. Ghusiya isolate shows 94\% identity with Fusarium oxysporum Strain in KP992931.1 Accession.

\section{Acknowledgement}

Every author owes a debt to his teachers. Therefore, I seize this opportunity to express my deep sense of indebtedness and profound gratitude to my major advisor Dr. L. F. Akbari, Professor and Head, Department of Plant Pathology, College of Agriculture, Junagadh Agricultural University, Junagadh for his keen interest, scientific guidance, constructive criticism and inspiration during the course of investigation and preparation of 
this dissertation. I would like to express special thanks to Mr. C. M. Bhaliya, Dr. J. R. Talaviya, Dr. K. K. Kanzariya, Ms. Shila Gevariya, other staff members and my colleagues of Department of Plant Pathology for their continues and ultimate support, guidance and help during the entire course of research work.

\section{References}

Agrawal, S. C. and Gupta, A. 2006. Variability of isolate of Fusarium oxysporum f. sp. ciceri causing wilt of chickpea. Indian J. Pulses Res., 25(2):156-157.

Barhate, B. G., Dake, G. N., Game, B. C. and Padule, D. N. 2006. Variability for virulence in Fusarium oxysporum f. sp. ciceri causing wilt of chickpea. Legume Res., 29(4):308-310.

Booth, C. (1971). The genus Fusarium, Commonwealth Mycological Institute, Kew (Surry), England, 137 pp.

Chauhan, S. K. 1962. Observations on certain symptoms in Fusarium wilt of gram (Cicer arietinum L.). Agra Uni. Res. (Sci.,), 11:285-294.

Dubey, S. C., Singh, S. R. and Singh, B. 2010. Morphological and pathogenic variability of Indian isolates of Fusarium oxysporum f. sp. ciceri causing chickpea wilt. Arch. Phytopathology Plant Protect., 43(2): $174-190$.

Gowda, S. J. M., P. Radhika, N. Y. Kadoo, L. B. Mhase, and V. S. Gupta. 2009. Molecular mapping of wilt resistance genes in chickpea. Mol. Breed., 24(2): 177-183.

Grewal, J. S., Pal, M. and Kulshreshtha, D. D. 1974. Fungi associated with gram wilt. Indian J. Genet. Pl. Br., 34:242-246.

Groenewald, S., Berg, N. V. D., Marasas. W. F. O. and Viljoen, A. 2006. Biological, physiological and pathogenic variation in a genetically homogenous population of Fusarium oxysporum f. sp. cubense. Australas. Plant Pathol., 35:401-409.

Gupta, O., Khare M. N. and Kotasthane, S. R. 1986. Variability among six isolates of Fusarium oxysporum f. sp. ciceri causing wilt of chickpea. Indian Phytopath., 39:279-281.

Gurjar, G. S., Giri, A. P. and Gupta, V. S. 2012. Gene expression profiling during wilting in chickpea caused by Fusarium oxysporum f. sp. ciceri. American J. Pl. Sci., 3: 190-201.

Haware, M. P. and Y. L. Nene. 1982. Races of Fusarium oxysporum f. sp. ciceri. Pl. Dis. 66(9): 809-810.

Haware, M. P., Nene, Y. L. and Natarajan, M. 1996. Survival of Fusarium oxysporum f. sp. ciceri. Pl. Dis., 66: 809-810.

Honnareddy, N. and Dubey, S. C. 2007. Morphological characterization of Indian isolates of Fusarium oxysporum f. sp. ciceri causing chickpea wilt. Indian Phytopath., 60(3):373-376.

Jalali, B. L. and Chand, H. 1992. Chickpea wilt. pp. 429-444 in: Plant Diseases of International Importance. Vol. 1. Diseases of Cereals and Pulses. U. S. Singh, A. N. Mukhopadhayay, J. Kumar, and H. S. Chaube, eds. Prentice Hall, Englewood Cliffs, New Jersey.

Kala, C., Gangopadhyay, S. and Godara S. L. 2016. Eco-friendly management of wilt caused by Fusarium oxysporum f. sp. ciceri in chickpea. Leg. Res., Int. J., 39(1):129-134.

Mandhare, V. K., Deshmukha, V. K., Patil, J. V., Kale, A. A. and Chavand, U. D. 2011. Morphological, pathogenic and molecular characterization of Fusarium oxysporum f. sp. ciceri isolates from Maharashtra, India. Indonesian J. Agri. Sci., 12(2):47-56.

Navas Cortes, J. A., Hau, B. and Jimenez Diaz, R. M. 2000. Yield loss in chickpea in relation to development to 
Fusarium wilt epidemics. Phytopathology, 90:1269-1278.

Nene, Y. L., Sheila, V. K. and Sharma, S. B. 1996. A world list of chickpea and pigeonopea pathogens, $5^{\text {th }}$ edn. ICRISAT, Patancheru, India, pp. 27.

Nikam, P. S., Jagtap, G. P. and Sontakke, P. L. 2011. Survey, surveillance and cultural characteristics of chickpea wilt caused by Fusarium oxysporum f. sp. ciceri. Afr. J. Agril. Res., 6(7):19131917.

Pande, S., Rao, J. N. and Sharma, M. 2007. Establishment of the chickpea wilt pathogen $F$. oxysporum f. sp. ciceri in the soil through seed transmission. Plant. Pathol. J., 23(1):3-6.

Patel, S. T. and Anahosur, K. H. 2001. Variability among the isolates of Fusarium oxysporum f. sp. ciceri and Fusarium solani from chickpea. Madras Agril. J., 88(3):124-126.

Patil, P. D., Mehetre, S. S., Mandare, V. K. and Dake, G. N. 2005. Pathogenic variation among Fusarium isolates associated with wilt of chick pea. Ann. Pl. Prot. Sci., 13:427-430.

Paulkar, P. K. and Raut, B. T. (2004). Variability among the isolates of Fusarium oxysporum f. sp. ciceri. J. Mycol. Plant Pathol., 34(1):20-23.

Prasad, N. and Padwick, G. W. 1939. The genus Fusarium II. A species of Fusarium as a cause of wilt of gram
(Cicer arietinum L.). Indian J. Agri. Sci., 9:371-380.

Rangaswamy, G. and Mahadevan, A. 1999. Diseases of crop plants in India (4th edition) Prentice Hall of India Pvt. Ltd., New Delhi, pp. 607.

Rosa, M. A., Martin, E., Evelia, A. F., Alfonso, S. and Gutierrez, A. 2011. Morphological variability and races of Fusarium oxysporum f. sp. ciceri associated with chickpea (Cicer arietinum) crops. American J. Agril. and Bil. Sci., 6(1):114-121.

Sharma, M., Varshney, R. K., Rao, J. N., Kannan, S., Hoisington, D. and Pande, S. 2009. Genetic diversity in Indian isolates of Fusarium oxysporum f. sp. ciceri chickpea wilt pathogen. Afr. J. Biotech., 8(6):1016- 1023.

Singh, R. K., Abul Hasan and Chaudhary, R. G. 2010. Variability in Fusarium oxysporum f. sp. ciceri causing vascular wilt in chickpea. Arch. Phytopath. Pl. Prot., 43(10):987-995.

Tuite, J. 1969. Plant Pathological MethodsFungi and Bacteria. Burgess Publishing Company Minneapolis, Minnesotta, p. 239.

Yadav J., Verma, J. P., Tiwari, K. N. 2011. Plant growth promoting activities of fungi and their effect on chickpea plant growth. Asian J. Biol. Sci., 4 (3): 291299.

\section{How to cite this article:}

Golakiya, B.B., M.D. Bhimani and Akbari, L.F. 2018. Characterization of Indian Isolates of Fusarium oxysporum f. sp. ciceri Causing Chickpea Wilt. Int.J.Curr.Microbiol.App.Sci. 7(03): 1152-1162. doi: https://doi.org/10.20546/ijcmas.2018.703.137 